Матеріали XIV Всеукраїнської науково-практичної конференції з міжнародною участю, присвяченої 60-річчю ТДМУ, “СУЧАСНІ ПІДХОДИ ДО ВИЩОЇ МЕДИЧНОЇ ОСВІТИ В УКРАЇНІ”

УДК 378.091.12:005.962.131

DOI 10.11603/me.2414-5998.2017.3.7756

Т. М. Бойчук, І. В. Геруш, В. М. Ходоровський, Є. П. Ткач

Вищий державний навчальний заклад Украӥни “Буковинський державний медичний університет”, м. Чернівці

\title{
РЕЙТИНГУВАННЯ ДІЯЛЬНОСТІ НАУКОВО-ПЕДАГОГІЧНИХ ПРАЦІВНИКІВ ТА КАФЕДР - ВАГОМА СКЛАДОВА СИСТЕМИ ВНУТРІШНЬОГО ЗАБЕЗПЕЧЕННЯ ЯКОСТІ ОСВІТИ У ВИЩОМУ ДЕРЖАВНОМУ НАВЧАЛЬНОМУ ЗАКЛАДІ УКРАЇНИ “БУКОВИНСЬКИЙ ДЕРЖАВНИЙ МЕДИЧНИЙ УНІВЕРСИТЕТ”
}

T. M. Boichuk, I. V. Herush, V. M. Khodorovskyi, Ye. P. Tkach

Higher State Educational Establishment of Ukraine "Bukovinian State Medical University", Chernivtsi

\section{RANKING OF SCIENTIFIC-PEDAGOGICAL STAFF AND DEPARTMENTS ACTIVITY - A SIGNIFICANT COMPONENT OF INTERNAL QUALITY ASSURANCE OF EDUCATION IN THE HIGHER STATE EDUCATIONAL ESTABLISHMENT OF UKRAINE “BUKOVINIAN STATE MEDICAL UNIVERSITY”}

\footnotetext{
У статті висвітлено роботу системи рейтингового оцінювання діяльності викладачів та кафедр у ВДНЗ України “Буковинський державний медичний університет” у рамках моніторингу належної якості науково-педагогічного персоналу, визначені найбільш вагомі індикатори діяльності серед основних напрямів роботи, підтверджені переваги дистанційної форми рейтингової звітності.

Ключові слова: рейтингове оцінювання; індикатори діяльності; якість освіти.

The system of rating evaluation of academic staff and departments in the Higher State Educational Establishment of Ukraine "Bukovinian State Medical University" under the monitoring of proper quality of scientific-pedagogical staff is covered. The most significant indicators of activity among the major areas of work are defined; the advantages of remote rating report submission are proved.
}

Key words: rating assessment; indicators of activity; quality of education.

Вступ. Відповідно до Закону України від 01.07.2014 p. № 1556-VII “Про вищу освіту” вищі навчальні заклади повинні мати розроблені процедури та критерії (внутрішні індикатори якості), які б могли засвідчити високу кваліфікацію та достатній фаховий рівень співробітників, що здійснюють викладацьку діяльність [1]. Постановою Кабінету Міністрів України від 30.12.2015 р. № 1187 “Про затвердження Ліцензійних умов провадження освітньої діяльності закладів освіти” (пункт 5 приміток Додатка 12) уведені показники для визначення рівня наукової та професійної активності науково-педагогічних (наукових) працівників (зовнішні індикатори якості) [2].

Тобто у вищих навчальних закладах необхідно не тільки проводити оцінку якості науково- педагогічного персоналу (молодих викладачів 3 обов'язковим базовим рівнем компетентності при процедурі відбору та призначенні на посаду, викладачів з тривалим професійним стажем, які постійно вдосконалюють фахову майстерність та демонструють високі професійні уміння), але й здійснювати моніторинг відповідності кадровим вимогам провадження освітньої діяльності за встановленими уніфікованими державними критеріями для осіб, що іï проваджують [1-3].

Для забезпечення належного рівня якості науково-педагогічного персоналу, контролю відповідності визначеним кадровим вимогам та внутрішнім критеріям провадження освітньої діяльності у ВДНЗ України “Буковинський державний медичний університет” впроваджена процедура рей-

(c) Т. М. Бойчук, І. В. Геруш, В. М. Ходоровський, Є. П. Ткач 
тингування - це ціла багаторівнева система оцінки діяльності кафедр та викладачів за основними напрямами роботи (навчально-методична робота, наукова діяльність, кадрова політика, міжнародне, державне та галузеве визнання, громадська, організаційна і виховна діяльність, лікувальнодіагностична та організаційно-методична робота в лікувальних закладах).

Основними завданнями рейтингового оцінювання є:

- розроблення і використання єдиних комплексних критеріїв для оцінювання і контролю рівня та ефективності діяльності науково-педагогічних (педагогічних) працівників та кафедр університету;

- формування управлінських кадрів і науковопедагогічного складу університету з урахуванням їх індивідуального внеску у підвищення рейтингу університету в цілому;

- вдосконалення діяльності та розвиток університету через критичний, серйозний і відвертий аналіз колективом результативності власної праці;

- активізація та стимулювання видів діяльності, які орієнтують і сприяють підвищенню рейтингу університету в цілому, та створення умов для професійного зростання усіх працівників;

- стимулювання нових напрямів наукових досліджень та вдосконалення науково-методичної основи викладацької діяльності;

- виявлення недоліків і проблемних питань у діяльності науково-педагогічних (педагогічних) працівників та кафедр;

- формування системи матеріального і морального стимулювання діяльності науково-педагогічних (педагогічних) працівників для подальшого їх заохочування [4].

Мета роботи - визначення та аналіз найбільш вагомих індикаторів діяльності викладачів та кафедр у динаміці та виявлення переваг дистанційної форми рейтингової звітності на основі даних роботи системи рейтингового оцінювання діяльності викладачів та кафедр у ВДНЗ України “Буковинський державний медичний університет” у рамках моніторингу належної якості роботи науково-педагогічного персоналу.

Основна частина. Згідно з Положенням про рейтингову систему оцінювання діяльності кафедр та викладачів ВДНЗ України “Буковинський державний медичний університет” (зі змінами та доповненнями), наказами ректора університету четвертий рік поспіль проведено рейтингове оцінювання діяльності викладачів та кафедр університету. Процедура рейтингу та методика його розрахунку залишаються попередніми [4]. Перелік показників змінено і доповнено. У 2016 році проведено додаткову компіляцію рейтингу шляхом включення показників для визначення рівня наукової та професійної активності відповідно до кадрових вимог, які передбачені ліцензійними умовами провадження освітньої діяльності закладів освіти [2]. Колективно рейтинговою комісією визначено для кожного нового показника вагу балів, вид діяльності, матеріали і форми підтвердження нових позицій рейтингу.

Рейтинг характеризується IT-оптимізованою динамічністю, а це дозволяє вносити зміни та проводити його корекцію, отримувати статистичний матеріал для основних підрозділів та служб університету, на підставі чого навчальному, науковому, лікувальному, міжнародному та іншим відділам, а також кафедрам університету можна корегувати плани діяльності, розробляти заходи щодо оптимізації своїх напрямів роботи тощо. Для науково-педагогічних (педагогічних) працівників така форма рейтингу дозволяє не тільки підвищити ефективність та результативність власної професійної діяльності, але й забезпечити прозорість та об’єктивність оцінювання діяльності кожного викладача та структурних підрозділів університету, полегшити доступ до інформації про особисті напрацювання та здобутки для керівників університету, структурних підрозділів (спосіб виробничого “піару”).

Щорічно оцінка діяльності викладачів та кафедр проводиться рейтинговою комісією, контролюється співробітниками навчального, наукового, міжнародного та лікувального відділів.

Рейтинг ресурсно забезпечується роботою програми “Електронний журнал успішності” (Webпрограма, розроблена на основі мови програмування PHP 5.4 та сервера бази даних MySQL 5.1, електронна адреса: ez.bsmu.edu.ua), що моніторується навчальним відділом із сектором моніторингу якості освіти та інформаційно-аналітичного забезпечення. Переваги електронної форми подання рейтингу - безсумнівні: дистанційність та можливість подання матеріалів для верифікації особистого рейтингу в електронному вигляді (гіперпосилання, прикріплення файлів різних форматів тощо).

Основною метою щорічного рейтингу залишається встановлення недоліків, їх аналіз та спря- 
мована корекція плану діяльності викладачів та кафедр на подальший період роботи за основними напрямами.

Динаміка показників проведеного рейтингування стабільно залишається позитивною. Середній рейтинговий бал у перерахунку на одного викладача університету за підсумком рейтингу щорічно зростає (від 188 балів за 2012-2013 н. р. до 445 балів за 2015-2016 н. р.) (табл. 1). Зростання чисельності набраних балів викладачами відбувається також за рахунок залучення всіх співробітників до формування показників рейтингу. Кожен співробітник на кожному факультеті щороку може долучитись до внесення змін чи доповнень до рейтингових показників діяльності, а отже, він є учасником процесу управління рівнем якості науково-педагогічних працівників в університеті.

За результатами рейтингу за минулий навчальний рік, порівняно з іншими трьома періодами (табл. 1), стабільно найбільшу кількість балів набирають співробітники університету, що обіймають посади завідувачів кафедр та професорів, найменшу - асистенти та викладачі. Відзначено певний непропорційний перерозподіл балів між підгрупами викладачів у 2016 році за рахунок включення нових показників, відповідно до кадрових вимог провадження освітньої діяльності. Встановлено значне зростання кількості набраних балів за результатами діяльності професорів та завідувачів кафедр, асистентів та викладачів і зниження кількості балів серед доцентів та старших викладачів.

За основними розділами роботи перевага надається науковій діяльності, за якою співробітники четвертий рік поспіль набирають найбільшу кількість балів у перерахунку на одного викладача. Другим напрямом діяльності, за кількістю набраних балів, стабільно залишається навчально-методична робота, третім - лікувальна, далі - міжнародне, державне визнання, громадська та виховна діяльність і кадрова політика.

Прослідковується постійне зростання рейтингових балів за основними напрямами роботи впродовж 4-х років (див. табл. 2 та табл. 3). Проте визначено певні коливання щодо рейтингових балів в абсолютному значенні та відсотковому співвідношенні напрямів “Кадрова політика” і “Лікувальнодіагностична та організаційно-методична робота в лікувальних закладах”, що в умовах появи нових показників рейтингу є закономірним. Але окремі позиції зазначених напрямів все ж потребують можливої корекції у майбутньому.

У таблиці 4 наведені результати рейтингу 2016 року за видами діяльності, яким надають перевагу різні за типом кафедри (клінічні та теоретичні). 3 результатів аналізу видно, що більш вагомим є внесок діяльності клінічних кафедр у наукову роботу університету, а теоретичних - у навчально-методичну, хоча більш гармонійним все ж виглядає співвідношення балів

Таблиця 1. Усереднені показники рейтингу діяльності викладачів БДМУ за 2012-2016 рр.

\begin{tabular}{|l|c|c|c|c|}
\hline \multirow{2}{*}{\multicolumn{1}{|c|}{ Посада }} & \multicolumn{4}{|c|}{ Середній рейтинговий бал } \\
\cline { 2 - 5 } & 2012-2013 н. p. & 2013-2014 н. p. & 2014-2015 н. p. & $2015-2016$ н. p. \\
\hline Завідувач кафедри, професор & 461 & 720 & 820 & 1058 \\
\hline Доцент, ст. викладач & 182 & 284 & 468 & 428 \\
\hline Асистент, викладач & 106 & 165 & 220 & 270 \\
\hline Загалом & 188 & 292 & 399 & 445 \\
\hline
\end{tabular}

Таблиця 2. Усереднені показники рейтингу викладачів БДМУ за напрямами діяльності за 2012-2016 рр.

\begin{tabular}{|l|c|c|c|c|}
\hline \multirow{2}{*}{\multicolumn{1}{|c|}{ Вид діяльності }} & \multicolumn{3}{|c|}{ Середній рейтинговий бал/на 1 викл. } \\
\cline { 2 - 5 } & $2012-2013$ н. р. & $2013-2014$ н. р. & $2014-2015$ н. p. & $2015-2016$ н. p. \\
\hline Навчально-методична робота & 61,7 & 59,6 & 107 & 137,5 \\
\hline Наукова діяльність & 105 & 147 & 240 & 296,1 \\
\hline Кадрова політика & 10,5 & 13,3 & 12 & 16,92 \\
\hline $\begin{array}{l}\text { Міжнародне, державне та } \\
\text { галузеве визнання, громадська, } \\
\text { організаційна та виховна } \\
\text { діяльність }\end{array}$ & 5,6 & 8,3 & & 23,3 \\
\hline $\begin{array}{l}\text { Лікувально-діагностична та } \\
\text { організаційно-методична робота } \\
\text { в лікувальних закладах }\end{array}$ & 15,5 & 26,7 & 28,5 & \\
\hline
\end{tabular}



60-річчю ТДМУ, “СУЧАСНІ ПЦДХОДИ ДО ВИЩОЇ МЕДИЧНОЇ ОСВІТИ В УКРАЇНІ”

Таблиця 3. Показники рейтингу викладачів БДМУ за напрямами діяльності у відсотковому співвідношенні за 2012-2016 pp.

\begin{tabular}{|l|c|c|c|c|}
\hline \multirow{2}{*}{ Вид діяльності } & \multicolumn{4}{|c|}{ Відсоток } \\
\cline { 2 - 5 } & $2012-2013$ н. p. & 2013-2014 н. p. & 2014-2015 н. p. & 2015-2016 н. p. \\
\hline Навчально-методична робота & 31,1 & 23,1 & 26,8 & 28,5 \\
\hline Наукова діяльність & 53,0 & 57,0 & 60,1 & 2,2 \\
\hline Кадрова політика & 5,3 & 5,2 & 3,0 & 3,4 \\
\hline $\begin{array}{l}\text { Міжнародне, державне та } \\
\text { галузеве визнання, громадська, } \\
\text { opганізаційна та виховна } \\
\text { діяльність }\end{array}$ & 2,8 & 4,4 & 3,0 & 4,8 \\
\hline $\begin{array}{l}\text { Лікувально-діагностична та } \\
\text { організаційно-методична робота } \\
\text { в лікувальних закладах }\end{array}$ & 7,8 & 10,4 & 7,1 & 100 \\
\hline Всього & 100 & 100 & 100 & \\
\hline
\end{tabular}

Таблиця 4. Якісна “клініко/теоретична” складова рейтингових балів за всіма напрямами діяльності БДМУ в 2016 році (рейтинговий період 2015-2016 н. р.)

\begin{tabular}{|l|c|c|c|}
\hline \multirow{2}{*}{\multicolumn{2}{|c|}{ Вид діяльності }} & \multicolumn{3}{|c|}{ Розподіл рейтингових балів } \\
\cline { 2 - 4 } & клінічні кафедри & теоретичні кафедри & загалом \\
\cline { 2 - 4 } & абс./викл. & абс./викл. & абс./викл. \\
\hline Навчально-методична робота & 103,6 & 187,3 & 137,5 \\
\hline Наукова діяльність & 312,4 & 272,1 & 296,1 \\
\hline Кадрова політика & 11,4 & 7,82 & 16,92 \\
\hline $\begin{array}{l}\text { Міжнародне, державне та галузеве визнання, } \\
\text { громадська, організаційна та виховна діяльність }\end{array}$ & 18,7 & 13,0 & 23,3 \\
\hline $\begin{array}{l}\text { Лікувально-діагностична та організаційно- } \\
\text { методична робота в лікувальних закладах }\end{array}$ & 36,1 & 4,4 & \\
\hline
\end{tabular}

у “навчально-методичній/науковій” пропорції на кафедрах теоретичного спрямування. "Науковість” клінічних кафедр не можна розглядати як недолік, це зумовлено більш жвавою динамікою кадрів в університеті, написанням великої кількості наукових дисертаційних робіт, реалізацією грантових проектів, проведенням клінічних досліджень тощо.

За результатами аналізу рейтингових показників, встановлено, що викладачі університету набрали 51 тис. 910 балів (28,5\% від загальної кількості) за здійснення навчально-методичної роботи (табл. 5). До прикладу, щоб оцінити інтенсивність її виконання та інтелектуальну ресурсність, наведемо кількість балів, що відведено для написання навчального посібника з грифом профільних міністерств - всього 200 балів, тез навчально-методичного спрямування до нефахового видання - всього 5 балів тощо. У розгорнутому вигляді (див. табл. 5) подано 11 найбільш вагомих індикаторних показників навчальної діяльності викладачів, за якими було набрано у 2016 році найбільшу кількість балів. Всього за цим напрямом діяльності передбачено 33 індикаторні показники.
За результатами аналізу рейтингу було також встановлено, що викладачі університету набрали майже 150 тис. балів (61,2 \% від загальної кількості) за здійснення наукової роботи (табл. 6). У більш детальному вигляді (див. табл. 6) подано 11 найбільш вагомих індикаторних показників наукової діяльності викладачів, за якими було набрано у 2016 році найбільшу кількість балів. Всього за цим напрямом діяльності передбачено 35 індикаторних показників. До прикладу, для оцінки масштабності наукової роботи співробітників університету у 2015-2016 н. р., наведено аналіз типів публікацій наукових статей залежно від рівня наукових видань, а також їх абсолютну кількість (табл. 7).

Всього аналізу піддавались 143 індикаторних показники, що включені до системи рейтингового оцінювання за наведеними вище п’ятьма напрямами діяльності.

За результатами проведеного рейтингу визначено ефективність та дієвість системи моніторингу якості науково-педагогічного персоналу в університеті через суттєве збільшення кількості наукових 
Матеріали XIV Всеукраїнської науково-практичної конференції з міжнародною участю, присвяченої 60-річчю ТДМУ, “СУЧАСНІ ПІДХОДИ ДО ВИЩОЇ МЕДИЧНОЇ ОСВІТИ В УКРАЇНІ”

Таблиця 5. Найбільш вагомі індикаторні показники навчальної діяльності викладачів БДмУ за результатами рейтингу в 2016 році (рейтинговий період 2015-2016 н. р.)

\begin{tabular}{|c|c|c|}
\hline Показники діяльності & $\begin{array}{l}\text { Набрано } \\
\text { балів, абс. }\end{array}$ & $\begin{array}{l}\text { Набрано } \\
\text { балів, \% }\end{array}$ \\
\hline $\begin{array}{l}\text { Стаття навчально-методичного спрямування в журналі, збірнику - закордонному, } \\
\text { вітчизняному (фаховому, нефаховому) }\end{array}$ & 13457,5 & 25,9 \\
\hline $\begin{array}{l}\text { Видання навчального, навчально-методичного посібника (у т. ч. електронного) з } \\
\text { грифом МОН України, МОЗ України, ЦМК з ВМО МОЗ України, рекомендованого } \\
\text { до друку Вченою радою БДМУ }\end{array}$ & 11072,5 & 21,3 \\
\hline $\begin{array}{l}\text { Тези навчально-методичного спрямування в журналі, збірнику - закордонному, } \\
\text { вітчизняному (фаховому, нефаховому) }\end{array}$ & 4387,1 & 8,5 \\
\hline $\begin{array}{l}\text { Видано колективом кафедри підручник (у т. ч. національний) з грифом МОН } \\
\text { України, МОЗ України (за 1) або дольове співавторство у національному підручнику } \\
\text { з грифом МОН України або МОЗ України, який виданий в іншому авторському } \\
\text { колективі }\end{array}$ & 4320,0 & 8,3 \\
\hline Проведення навчальних занять іноземною мовою & 3760,0 & 7,2 \\
\hline $\begin{array}{l}\text { Розробка стандартів вищої освіти - вищого навчального закладу (ОПП, ОНП, } \\
\text { варіативні частини ОПП та ОКХ, ЗД тощо) }\end{array}$ & 3400,0 & 6,5 \\
\hline $\begin{array}{l}\text { Складання тестових завдань для первинного банку тестів Центру тестування МО3 } \\
\text { України (за } 1 \text { тестове завдання) }\end{array}$ & 2661,8 & 5,1 \\
\hline $\begin{array}{l}\text { Персональна підготовка студента-призера II етапу всеукраїнських студентських } \\
\text { предметних олімпіад }\end{array}$ & 2470,0 & 4,8 \\
\hline $\begin{array}{l}\text { Доповідь на навчально-методичному форумі - включеному до реєстру МОН } \\
\text { України, МОЗ України }\end{array}$ & 484,0 & 0,9 \\
\hline Внутрішньовузівська експертиза ТЗ для первинного банку тестів ЦТ МОЗ України & 746,6 & 1,4 \\
\hline Експертиза ТЗ у ЦТ МОЗ України (відповідно до листа ЦТ МОЗ України) & 640,0 & 1,2 \\
\hline Інші види діяльності & 4510,6 & 8,7 \\
\hline Всього & 51910,1 & 100 \\
\hline
\end{tabular}

Таблиця 6. Найбільш вагомі індикаторні показники наукової діяльності викладачів БДМУ за результатами рейтингу в 2016 році (рейтинговий період 2015-2016 н. р.)

\begin{tabular}{|l|c|c|}
\hline \multicolumn{1}{|c|}{ Показники діяльності } & $\begin{array}{c}\text { Набрано } \\
\text { балів, абс. }\end{array}$ & $\begin{array}{c}\text { Набрано } \\
\text { балів, \% }\end{array}$ \\
\hline Надруковано наукову статтю в українських, закордонних наукових виданнях & 71026,8 & 47,6 \\
\hline Опубліковані наукові тези в українських, закордонних наукових виданнях & 14470,3 & 9,7 \\
\hline $\begin{array}{l}\text { Доповідь на всеукраїнських науково-практичних конференціях, включених } \\
\text { до Державного реєстру, на національних конгресах, симпозіумах та з'їздах, } \\
\text { регіональних науково-практичних конференціях }\end{array}$ & 13257,3 & 8,9 \\
\hline Доповідь на міжнародних наукових форумах за кордоном (активна, пасивна) & 17544 & 11,76 \\
\hline Видання наукової монографії упродовж звітного навчального року & 5290 & 3,54 \\
\hline $\begin{array}{l}\text { Нововведення, включені до галузевого реєстру з грифом Укрмедпатентінформ } \\
\text { МОз України }\end{array}$ & 6200 & 4,15 \\
\hline Інформаційні листи з грифом Укрмедпатентінформ МОз України & 2500 & 1,68 \\
\hline Методичні рекомендації з грифом Укрмедпатентінформ МОз України & 1220 & 0,82 \\
\hline $\begin{array}{l}\text { Захист докторських та кандидатських дисертацій упродовж звітного } \\
\text { навчального року }\end{array}$ & 5300 & 3,55 \\
\hline Отриманий грант на навчання/наукову діяльність & 2100 & 1,41 \\
\hline $\begin{array}{l}\text { Інноваційна діяльність (патенти на корисну модель, на винахід/авторське право, } \\
\text { свідоцтва про реєстрацію авторського права) }\end{array}$ & 2218 & 1,5 \\
\hline Інші види робіт & 8098 & 5,39 \\
\hline Всього & 149225 & 100 \\
\hline
\end{tabular}



60-річчю ТДМУ, “СУЧАСНІ ПЦДХОДИ ДО ВИЩОЇ МЕДИЧНОЇ ОСВІТИ В УКРАЇНІ”

Таблиця 7. Вагові частки видань, у яких опубліковані наукові статті співробітників БДМУ у межах рейтингу наукової діяльності за 2015-2016 н. р.

\begin{tabular}{|l|c|c|c|}
\hline \multicolumn{1}{|c|}{ Показники діяльності } & $\begin{array}{c}\text { Набрано балів за } \\
\text { публікацію }\end{array}$ & $\begin{array}{c}\text { Абс. к-сть } \\
\text { публікацій }\end{array}$ & $\begin{array}{c}\text { \% від загального } \\
\text { показника }\end{array}$ \\
\hline $\begin{array}{l}\text { Надруковано наукову статтю у закордонному журналі, } \\
\text { який індексується у наукометричних базах }\end{array}$ & 34850,00 & 494 & 49,07 \\
\hline $\begin{array}{l}\text { Надруковано наукову статтю у вітчизняному журналі } \\
\text { (виданні), який індексуєтся у наукометричних базах або/ } \\
\text { та включений до Переліку фахових видань }\end{array}$ & 22990,60 & 875 & 32,37 \\
\hline $\begin{array}{l}\text { Надруковано наукову статтю у періодичному виданні, } \\
\text { яке включено до наукометричних баз Sсориз або Web of } \\
\text { Sсіепсе Соге Collection }\end{array}$ & 7158,00 & 73 & 10,08 \\
\hline $\begin{array}{l}\text { Надруковано наукову статтю в інших періодичних } \\
\text { виданнях }\end{array}$ & 3320,40 & 249 & 4,67 \\
\hline $\begin{array}{l}\text { Надруковано наукову статтю за кордоном у збірці } \\
\text { наукових праць }\end{array}$ & 2707,80 & 155 & 3,81 \\
\hline Всього & 71 026,8 & 1846 & 100 \\
\hline
\end{tabular}

і навчально-методичних публікацій та доповідей на наукових форумах в Україні та за кордоном, збільшення кількості стажувань викладачів, студентів та молодих науковців за кордоном, збільшення кількості угод про співпрацю із закордонними навчальними закладами, у т. ч. з Євросоюзу, збільшення кількості друкованих наукових та навчально-методичних видань, покращення грантової політики університету, стабільно успішну роботу з підготовки студентів-призерів Всеукраїнської студентської олімпіади, Всеукраїнського конкурсу студентських наукових робіт, спортивних змагань різних рівнів.

Висновки. Рейтингування діяльності науковопедагогічних працівників та кафедр є основною складовою системи внутрішнього забезпечення якості освіти у ВДНЗ України “Буковинський

\section{Список літератури}

1. Про вищу освіту : Закон України від 01.07.2014 p. № 1556-VII.

2. Про затвердження Ліцензійних умов провадження освітньої діяльності закладів освіти : Постанова Кабінету Міністрів України від 30.12.2015 р. № 1187.

3. Стандарти і рекомендації щодо забезпечення якості в Європейському просторі вищої освіти. - К. : Ленвіт,

\section{References}

1. Zakon Ukrainy «Pro vyshchu osvitu» vid 01.07.14 №1556-VII (2014). [The Higher Education Act of Ukraine of 01.07.14 №1556-VII] [in Ukrainian].

2. Postanova Kabinetu Ministriv Ukrainy vid 30.12.2015 № 1187 «Pro zatverdzhennia Litsenziinykh umov державний медичний університет”. Процедура рейтингу дозволяє здійснювати ефективний моніторинг якості науково-педагогічного персоналу університету відповідно до Закону України від 01.07.2014 р. № 1556-VII “Про вищу освіту” 3 урахуванням показників для визначення рівня наукової та професійної активності науково-педагогічних (наукових) працівників, які затверджені Постановою Кабінету Міністрів України від 30.12.2015 р. № 1187 “Про затвердження Ліцензійних умов провадження освітньої діяльності закладів освіти”. Аналіз рейтингу дозволяє виявити недоліки серед напрямів, видів роботи та здійснювати динамічне управління потоками інтелектуальної, фахово-компетентної продукції співробітників та кафедр університету.

2006. - 35 с.

4. Досвід впровадження системи рейтингового оцінювання діяльності викладачів та кафедр у Вищому державному навчальному закладі України “Буковинський державний медичний університет” / Т. М. Бойчук, I. В. Геруш, В. М. Ходоровський, Є. П. Ткач // Медична освіта. - 2016. - № 2. - С. 77-81.

provadzhennia osvitnoi diialnosti zakladiv osvity» (2015). [Resolution of the Cabinet of Ministers of July 7, 2014 № 1187 «Concerning Approval of Licence Provisions of Educational Activity of Educational Institutions Procedure»] [in Ukrainian]. 
3. Standarty i rekomendatsii shchodo zabezpechennia yakosti v Yevropeiskomu prostori vyshchoi osvity (2006). [Standards and guidelines for quality assurance at European higher education environment]. Kyiv: Lenvit [in Ukrainian].

4. Boichuk, T.M., Herush, I.V., Khodorovskyi, V.M., \& Tkach, Ye.P. (2016). Dosvid vprovadzhennia systemy reitynhovoho otsiniuvannia diialnosti vykladachiv ta kafedr u Vyshchomu derzhavnomu navchalnomu zakladi Ukrainy «Bukovynskyi derzhavnyi medychnyi universytet» [Experience of activity rating system of teachers and departments implementation at Bukovinian State Medical University]. Medychna osvita - Medical education, 2, 7781 [in Ukrainian].

Отримано 27.03.17

Електронна адреса для листування: gerush.igor@bsmu.edu.ua 